\title{
Evaluation of N-P-K-Ca-Mg dynamics in plum (Prunus salicina Lindl.) var. Horvin under nursery conditions
}

\section{Evaluación de la dinámica de N-P-K-Ca-Mg en ciruelo (Prunus salicina Lindl.) var. Horvin en condiciones de vivero}
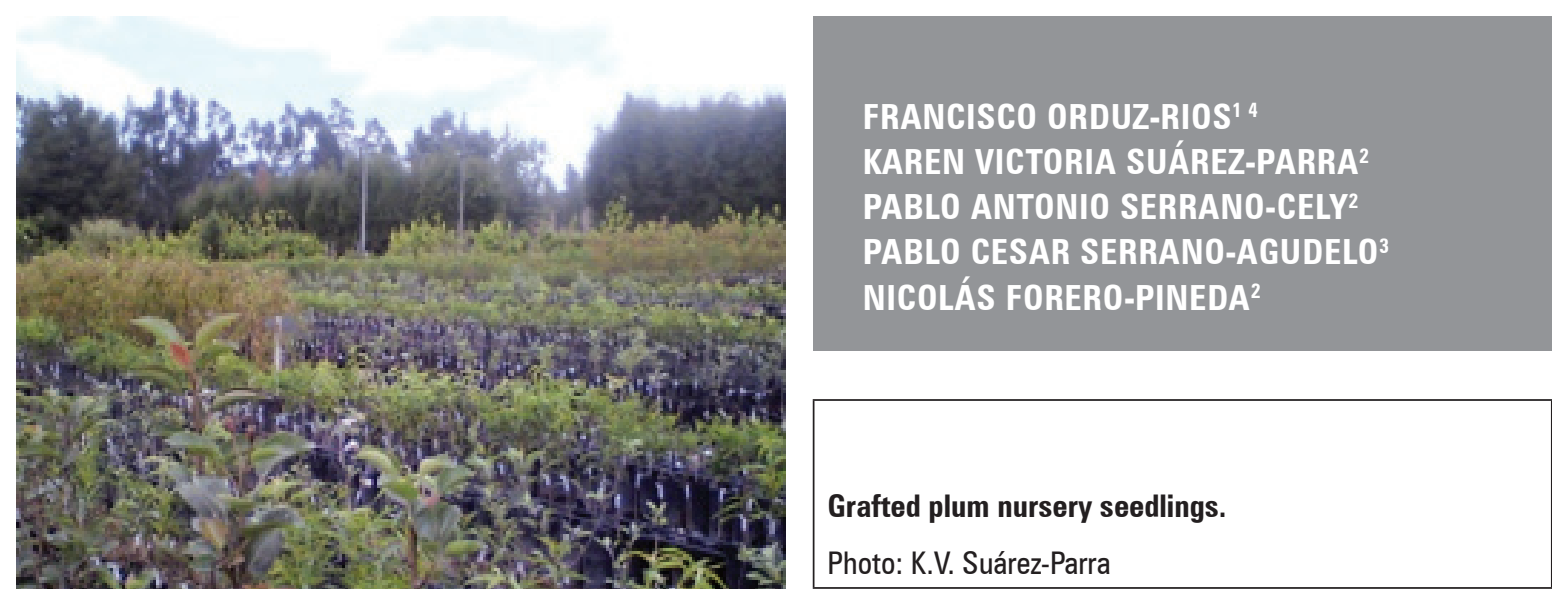

\begin{abstract}
Temperate fruit trees are a vital part of the economy of the Cundiboyacense highlands in Colombia. The nursery stage is important because it guarantees development at the final grow site. Little is known about the fertilization processes and nutritional dynamics of deciduous fruit trees in the early stages. This research aimed to evaluate the dynamics of N-P-K-Ca and Mg, along with SPAD units, in grafted plum (Prunus salicina) var. Horvin plants under the conditions of tropical highlands, which were evaluated at different growth points $(\mathrm{cm})$, from grafting to transplant. The foliar $\mathrm{N}$ concentrations were the highest, followed by the $\mathrm{K}$, $\mathrm{P}$ and $\mathrm{Mg}$ concentrations. Macronutrient concentrations in the first-stage of grafted nursery plants require nutritional balance for vegetative development and successful establishment at the definitive grow site.
\end{abstract}

Additional key words: deciduous fruit trees; plant nutrition; leaf tissue analysis; seedling production.

1 Universidad Pedagógica y Tecnológica de Colombia, Tunja (Colombia). ORCID Orduz-Ríos, F.: 0000-0002-3011-4936

2 Universidad Pedagógica y Tecnológica de Colombia, Facultad de Ciencias Agropecuarias, Grupo de Investigación GIPSO, Tunja (Colombia). ORCID Suárez-Parra, K.V.: 0000-0003-2736-9070; ORCID Serrano-Cely, P.A.: 0000-0002-12703024; ORCID Forero-Pineda, N.: 0000-0003-2421-5674

3 Universidad Nacional de Colombia, Bogota (Colombia). ORCID Serrano-Agudelo, P.C.: 0000-0002-2563-2050

4 Corresponding author. francorduz@hotmail.com 


\section{RESUMEN}

Los frutales de clima frío, corresponden a uno de los principales renglones económicos del altiplano cundiboyacense Colombiano. La etapa de vivero es la más importante para garantizar su desarrollo en sitio definitivo. Poco se sabe sobre los procesos de fertilización y dinámica nutricional de frutales caducifolios en etapas tempranas. Esta investigación tuvo como objetivo la evaluación de la dinámica del N-P-K-Ca y Mg, junto con las unidades SPAD en plantas injertadas de ciruelo (Prunus domestica) var. Horvin en condiciones del trópico alto evaluadas en diferentes puntos de crecimiento $(\mathrm{cm})$ desde la injertación, hasta las condiciones para el trasplante. Las concentraciones de $\mathrm{N}$ foliar se presentaron en mayor proporción, seguidos de $\mathrm{K}$, las concentraciones de $\mathrm{P}$ y $\mathrm{Mg}$ se registraron en menor proporción. Las concentraciones de macronutrientes en plantas injertadas de vivero en su primera etapa, requiere de un balance nutricional adecuado que permita el desarrollo vegetativo adecuado para su éxito en el establecimiento en sitio definitivo.

Palabras clave adicionales: frutales caducifolios; nutrición vegetal; análisis foliar; producción de plántulas.

Received for publication: 20-10-2020 Accepted for publication: 23-11-2020
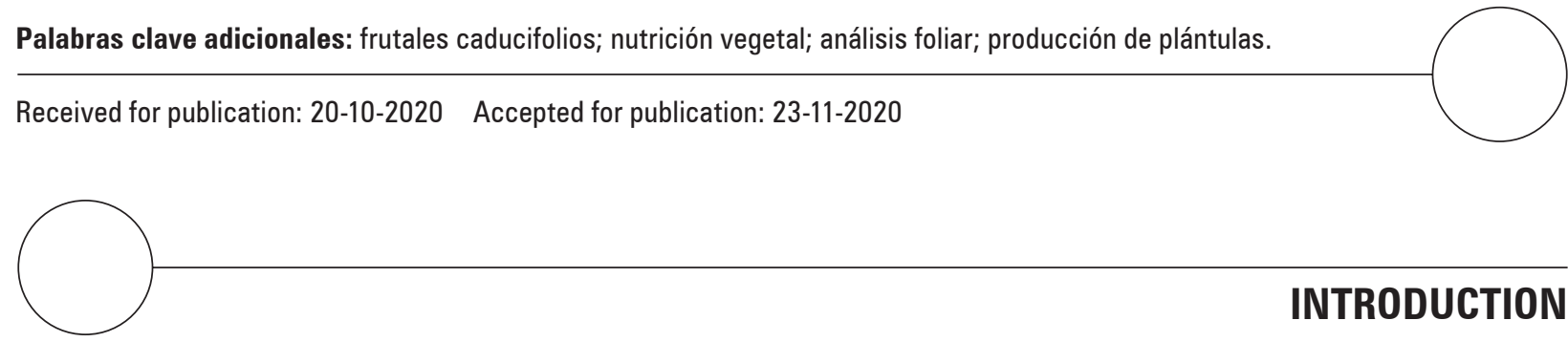

INTRODUCTION

In Colombia, Japanese plum fruit crops, classified botanically as Prunus salicina (Lindl.) (Cárdenas and Fischer, 2013), are mainly established in agro-ecological areas of the Cundiboyacense highlands (Campos, 2013; Puentes et al., 2019). The trend for the consumption of healthy food increased plum production by $55 \%$ between 2012 and 2017. Boyaca contributes $74 \%$ of Colombian production (Agronegocios, 2018). This crop develops easily in altitudinal zones between 1,800 and 2,450 $\mathrm{m}$ a.s.l. and has broad plasticity for adaptation to higher altitudes (Orjuela, 2017). Campos (2013) reported that 'Horvin' can withstand elevations up to 3,000 $\mathrm{m}$ a.s.l. Global warming means low winter chilling plum varieties will be especially important in the tropics (Saini et al., 2020), and the Andean highland areas will be more affected by climate change than lower valley zones (Fischer and Melgarejo, 2020).

Castro and Puentes (2012) confirmed that the successful cultivation of fruit trees requires healthy material and homogeneous variety characteristics, which are provided by specialized nurseries that are managed according to professional criteria of the highest level. Determining factors for plant production in this crop and others include an effective nutrient supply process in nursery stages although, currently, there is little knowledge on nutrition in this stage (Marschner, 2012). The production of plant propagation material involves nutritional studies on more important varieties (Lizarazo et al., 2016). One of the more important factors for fruit quality in plants under nursery conditions is nutrition; existing information does not sufficiently consider nutrient balance under the studied, local conditions, which could be applied as fertilization recommendations for the rest of Colombia (Fernández et al., 2016).

In some crops, fertilization plan recommendations include 15-d intervals with balanced formulas of N, P, $\mathrm{K}$ and $\mathrm{Mg}$, without any technical criteria. However, fertilization studies for production stages are widely consolidated (Meses, 2010; Novoa et al., 2018).

Information on the nutritional dynamics of crops in early stages facilitates synchronization of the physiological age with the amount of nutrients that a crop requires. Accumulation curves provide transcendental information for the establishment of nutrition programs that are focused on the correct use of fertilizers and cultivar quality (Ulloa et al., 2015). The objective of this research was to determine the behavior of the macronutrients $\mathrm{N}, \mathrm{P}, \mathrm{K}, \mathrm{Ca}$ and $\mathrm{Mg}$ in plum (Prunus salicina) var. Horvin plants under the agroecological conditions of tropical highlands.

\section{MATERIALS AND METHODS}

This research was conducted on plum var. Horvin in Paipa, Boyaca, Colombia (544'46.66" N, $\left.73^{\circ} 7^{\prime} 00.68^{\prime \prime} \mathrm{W}\right)$, with an average temperature of 
$14^{\circ} \mathrm{C}$, precipitation of $815 \mathrm{~mm}$ year ${ }^{-1}, 79.9 \%$ relative humidity and $4.44 \mathrm{~h} \mathrm{~d}^{-1}$ of sunlight (sunlight data obtained from the weather station located on the farm). This experiment was conducted from June 2017 to May 2018 with 45 plum plants (Prunus salicina Lindl.) grafted onto Gran Jarillo rootstock, which underwent cold hour accumulation $(\mathrm{CH})$ in a cold warehouse at $4^{\circ} \mathrm{C}$ for $8 \mathrm{~d}$. The expected accumulation was between 500 and $700 \mathrm{CH}$. Campos (2013) reported that 'Horvin' requires $300-400 \mathrm{CH}$.

Once established in the nursery area, the plants were sown in substrate (4 kg bags) with a mixture of soil and calcined rice husks, at a ratio of $3: 1$. The soil mixture had a sand-free texture, with the following chemical composition: $5.75 \mathrm{pH}, 7.44 \% \mathrm{OM}, \mathrm{N}$ at $46.26 \mathrm{mg} \mathrm{kg}^{-1}$; $\mathrm{P}$ at $62.58 \mathrm{mg} \mathrm{kg}^{-1}$; $\mathrm{Ca}$ at $3.40 \mathrm{cmol}$ $\mathrm{dm}^{-3} ; \mathrm{Mg}$ at $1.05 \mathrm{cmol} \mathrm{dm}^{-3}$; $\mathrm{K}^{2}$ at $0.92 \mathrm{cmol} \mathrm{dm}^{-3}$; and $5.42 \mathrm{cmol} \mathrm{dm}^{-3}$ CEC. Plant maintenance applications were carried out with the nutritional formula $\left(\mathrm{g} \mathrm{L}^{-1}\right)$ : nitric nitrogen $\left({\mathrm{N}-\mathrm{NO}_{3}}^{-}\right)$at 40.3 , ammonia nitrogen $\left(\mathrm{N}^{-} \mathrm{NH}_{4}{ }^{+}\right)$at 4.0 , phosphorus $\left(\mathrm{P}_{2} \mathrm{O}_{5}\right)$ at 20.4 , potassium $\left(\mathrm{K}_{2} \mathrm{O}\right)$ at 50.6 , calcium $(\mathrm{CaO})$ at 40 , magnesium $(\mathrm{MgO})$ at 18 , sulfur at 1 , iron at 1.12 , manganese at 0.12 , copper at 0.012 , zinc at 0.0254 , boron at 0.106 , molybdenum at 0.0012 , and cobalt at 0.001 (Nutriponics ${ }^{\circledR}$, Walco, Colombia), with a dose of $30 \mathrm{~mL} /$ plant per week at a concentration of $1 \%$. A substrate with a sand-free texture allows sufficient mineralization of nitrogen (Monsalve et al., 2017).

A total of 45 plants were established, which were grafted on the same day and at the same height, taking into account the height of the variety growth (2, $5,8,12,14,16,18$ and $20 \mathrm{~cm}$ in height); the heights were selected based on the morphological processes of formation of foliar structures in this variety, along with the fertilizer application timing, which was orientated and determined by the operator. Three similar individuals were selected; the plants were removed from the study area, washed with distilled water and packed in paper bags for transfer to the laboratory. For determination of the variables, it was necessary to use the entire plant. In the laboratory, the samples were processed and analyzed using the following methods: nitrogen: kjeldahl-colorimetry; phosphorus: wet digestion- colorimetry; and calcium, magnesium and potassium: wet digestion with atomic absorption. At the same time, the SPAD values were recorded with SPAD 502 plus chlorophyll after calibration (Konica Minolta).

Once the lab data were obtained, Microsoft Office Excel was used.

\section{RESULTS AND DISCUSSION}

The nitrogen concentrations (Fig. 1) decreased after the first weeks of graft growth $(7.7 \%)$, reaching a value of $2.5 \%$ at the end of the analysis. This may have been due to the fact that, as foliar growth begins, the $\mathrm{N}$ concentration in the total dry matter decreases over time because of a rapid increase in the amount of accumulated dry matter, presenting a dilution effect (Bugarín-Montoya et al., 2011). At the beginning, the accumulation of $\mathrm{N}$ in the vegetative organs was higher because of the development and formation of new tissue (cell division) (Bueno and Camargo, 2012; López and García, 2015).

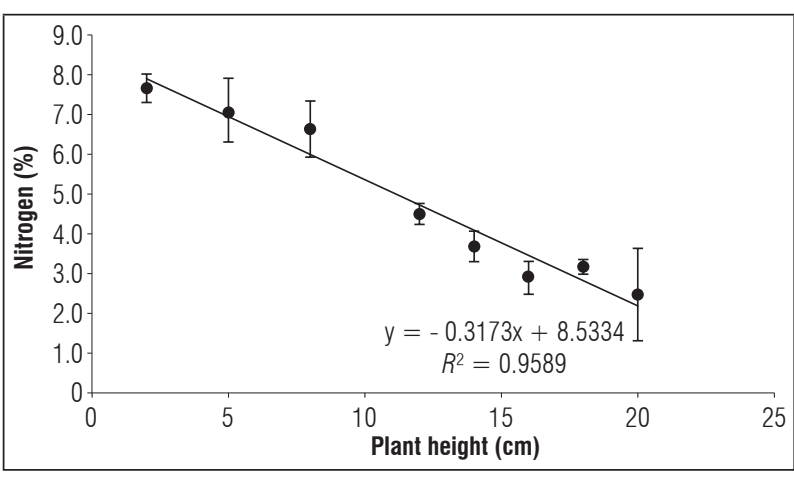

Figure 1. Behavior of nitrogen as a percentage during the growth stage after grafting plum plants. Error bars indicate standard error.

The lowest $\mathrm{N}$ concentration occurred after the flowering process with grafted buds, where the plant made use of $\mathrm{N}$ derived from re-mobilization from reserve organs (González and Del Pardo, 2011). The maximum decrease resulted from the growth of leaves and formation of branches, where high amounts of foliar $\mathrm{N}$ are needed, which are transported from the roots, leaving an insufficient amount for general plant requirements (Aburto-González et al., 2017; González-Pérez et al., 2018). Therefore, $\mathrm{N}$ fertilizer concentrations in these early stages must be applied with greater precision to meet plant requirements.

The nitrogen needs of plum fruit trees are lower than that of other species such as grapes but exceed those of orange and banana plants (Ciampitti and García, 2008). The concentrations of nitrogen and phosphorus obtained in this analysis were consistent with that found by Fernández et al. (2014), who reported that respective concentrations decline during the early growth stages of plum plants, until stable concentrations above $3.0 \%$ are reached; below-limit 
values are directly associated with plant water stress processes, as well as the occurrence of phenomena such as frost.

Asencio (2019) reported that, in plum plants, nitrogen concentrations in the first growth stage decline, as noted in this study. This author reported nitrogen concentrations between 4 and $2 \%$ during the first 30 days of graft growth and proposed that $\mathrm{N}$ concentrations and SPAD units in the early stage of growth do not have a close relationship because of plant tissue formation processes, especially in leaves during photosynthetic activation.

Phosphorus (Fig. 2) had values of $0.5 \%$, decreasing precipitously up to the heights of 12 and $16 \mathrm{~cm}$, with a concentration of $0.3 \%$, then increasing to $0.4 \%$ at the end of the evaluation. The lowest $\mathrm{P}$ concentration was in the vegetative growth stages, generally concentrated in the stems, with a lower amount in the roots. Phosphorus is very mobile in plants and can be translocated both upwards and downwards in metabolic processes. Therefore, it is absorbed to a greater extent by young leaves (Balta-Crisólogo et al., 2015).

Phosphorus is an important part of numerous fundamental compounds in plant metabolism, such as glut acid biosynthesis, lipid biosynthesis, chlorophyll and carotenoid synthesis, glycolysis and metabolism of organic acids, especially in leaves during photosynthetic activation (Marschner, 2012). Therefore, the activity of phosphorus within the plant is critical because it participates in virtually all metabolic processes, including photosynthesis and respiration (Mixquititla and Villegas, 2016).

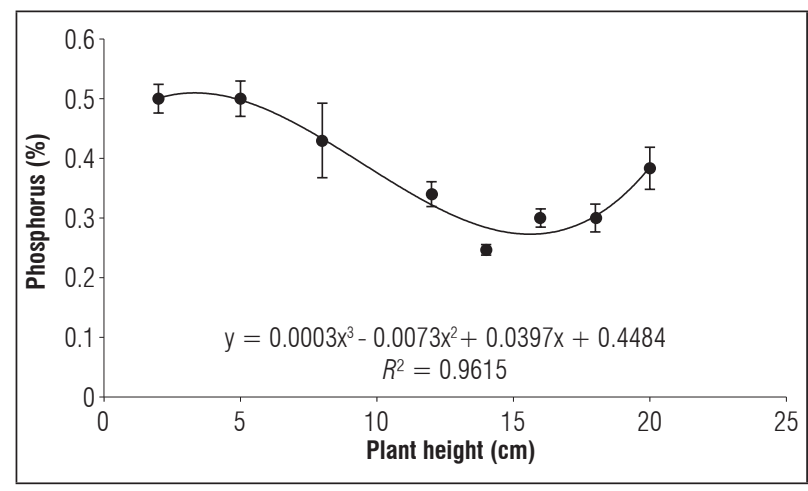

Figure 2. Behavior of phosphorus as a percentage during the growth stage after grafting plum plants. Error bars indicate standard error.
$\mathrm{P}$ is involved in the metabolism of sugars and in the storage and transfer of genetic information; it also promotes the initial formation and development of roots, the formation of the first stem, and the primary root, until the new plant begins to perform assimilation functions, increasing the plant's resistance to diseases. $\mathrm{P}$ is involved in the formation of nucleus proteins, nucleic acids and phospholipids and is vital to cell division, accumulation of energy in ATP and NADP compounds and phosphorylation phenomena (Cardona, 2017).

The foliar phosphorus concentrations exceeded the values reported by González et al. (2020), who reported phosphorus concentrations in the first stages of vegetative growth between 0.16 and $1.26 \%$. In general, $\mathrm{P}$ is found in root growth processes, so applications with fertilizers at this stage allow better expression for transplant process. An optimal N, P and $\mathrm{K}$ balance favors chlorophyll synthesis processes in true leaves (Latsague et al., 2014).

Potassium (Fig. 3) increased up to $12 \mathrm{~cm}$ (highest point $6.1 \%$ ), with a drastic decrease when the graft was $14 \mathrm{~cm}(2.7 \%)$, stabilizing at $18 \mathrm{~cm}$ and reaching a maximum point of $5.4 \%$ at $20 \mathrm{~cm}$. The $\mathrm{K}$ concentration was higher than the $\mathrm{P}$ concentration and lower than the $\mathrm{N}$ concentration over time, especially with irrigation, where the concentrations of both elements ( $\mathrm{K}: \mathrm{N}$ ratio) decreased, favoring the flowering processes, as reported by (Villanueva-Couoh et al., 2010).

Potassium tended to increase in the early stages as the vegetative organs grew, with a higher initial concentration in the roots that satisfied the growth and development needs of new roots. It reached higher

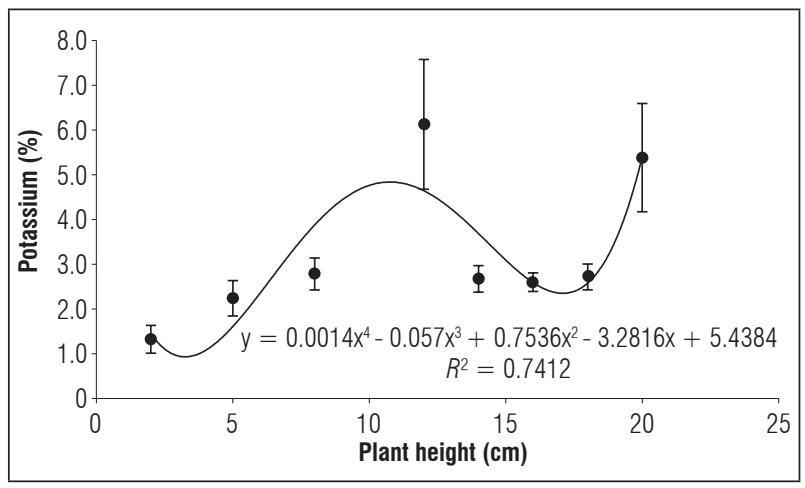

Figure 3. Behavior of potassium as a percentage during the growth stage after grafting plum plants. Error bars indicate standard error. 
concentrations in the first stages of growth, mostly moving towards the stems and leaves and later to the fruits and reproductive parts (Salas et al., 2014).

$\mathrm{K}$ is important plant growth because of its involvement in the interception of light and the production of dry matter and because it expresses the environmental effects of water intake and nutrients (Barragan, 2010). Potassium improves the quality and duration of crops and relieves stress conditions. In addition, it activates many enzymes that are essential in photosynthesis, respiration, starch synthesis, and proteins and is involved in the transport of photoassimilates. In addition, $\mathrm{K}$ is an ion that plays a key role in cellular osmoregulation (Martínez and Garcés, 2010).

Calcium (Fig. 4) had an almost constant behavior, increasing significantly as growth increased, varying between 0.7 and $1.1 \%$. Initial calcium concentrations in plants may be specific because plants mainly deplete calcium from the soil and cannot mobilize it from old tissue towards new shoots. Therefore, concentrations are not sufficient since calcium cannot be mobilized to new growth organs (Marschner, 2012).

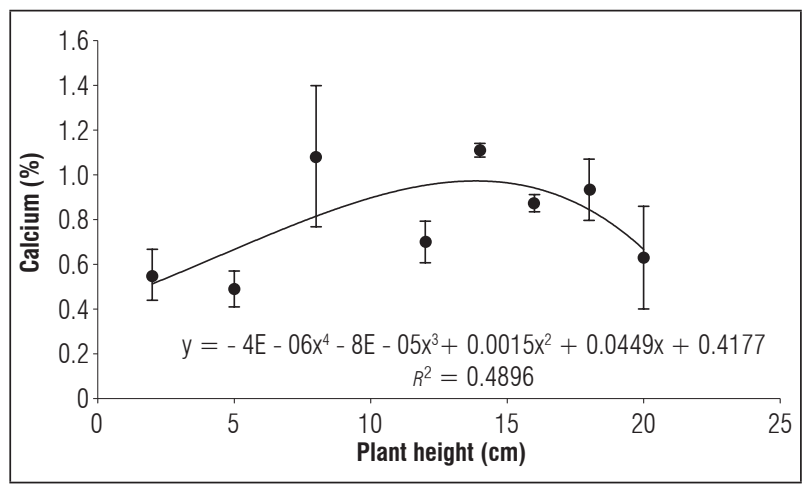

Figure 4. Behavior of calcium as a percentage during the growth stage after grafting plum plants. Error bars indicate standard error.

Calcium concentrations in young fruit trees are always lower than in adult fruit trees, possibly because of poor foliar development that limits absorption (García, 2011). The calcium concentrations in this study were similar to those reported by Lema et al. (2010), who stated that calcium accumulates more in organs such as stems and roots, with an average amount in mature leaves.

Calcium has a very important role in stabilizing the cell membrane, while maintaining selective permeability and integrity. Calcium ions act on pectin chains to form bridges, increasing the strength of the cell wall, and also positively influence membrane phospholipids and monogalactosyldiacylglycerol concentrations, preserving membrane integrity not only by postponing changes in senescence-related membrane lipids but also by increasing membrane restructuring processes (Rincón and Martinez, 2015).

Calcium is used in cell wall synthesis, a structural component of the middle layer, which separates newly formed cells. The average plant content is highly variable $(0.5-2 \%)$, and transport is highly mobile in the xylem but motionless in the phloem. It participates in the formation of mitotic spindle during cell division and is necessary for normal cell membrane functions. It acts as a cofactor of numerous enzymes that play a primary role in the elasticity and elongation of young plant cells (Jiménez, 2017).

Magnesium (Fig. 5) was mostly stable during the entire evaluation $(0.2-0.4 \%)$, with the highest peak when the graft was $8 \mathrm{~cm}$ high, with a percentage of $0.7 \%$. The calcium was similar to $\mathrm{P}$ but lower than the concentrations of $\mathrm{N}, \mathrm{K}$ and $\mathrm{Ca}$, possibly because of the remobilization of magnesium to reserve organs, which, unlike calcium, has greater mobility in the phloem (García, 2011).

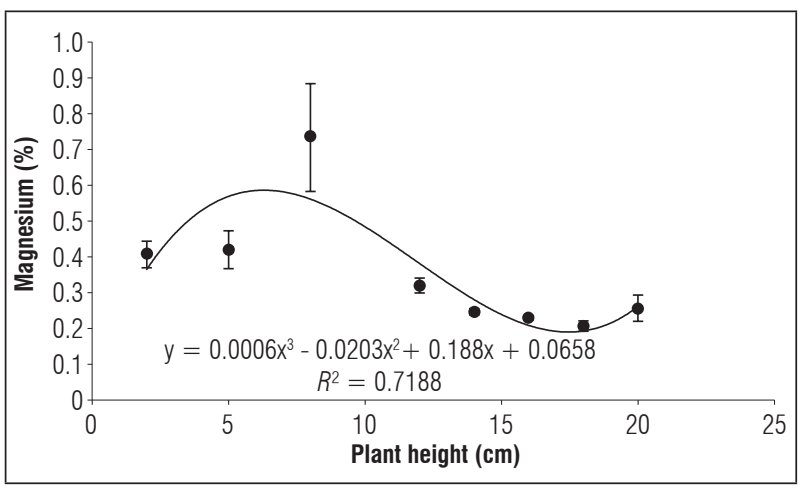

Figure 5. Magnesium behavior as a percentage during the first stages of growth after grafting plum plants. Error bars indicate standard error.

Magnesium accumulated in the aerial graft can be translocated from old leaves on the rootstock to young leaves on the graft (Jiménez, 2017). Magnesium is an essential macroelement for the growth and development of plants, so an adequate supply should be provided, preferably in the early stages of growth to ensure tissue quality (García-Ávila et al., 2015; Ube, 2019). 
Magnesium is a constituent of ribosomes and is the main atom of chlorophyll, helping protein synthesis and forming part of energy transfer reactions (ATP and enzymes). This element is specifically required by a large number of enzymes involved in the transfer of phosphates, is involved in photosynthesis, carbohydrate metabolism and nucleic acid synthesis, and is related to the movement of carbohydrates from leaves to the top (Marschner, 2012).

In other plants, such as tomatoes, Parra et al. (2010) reported concentrations of $0.5 \%$ magnesium in young plants and a 70/30 ratio to foliar nitrogen concentrations, consistent with this study, which can be explained by the form and level of nitrogen nutrition that influenced the balance of anions and cations in the plants. That is, increasing ammonium levels stimulates its absorption and that of anions that compensate for the load. In contrast, plants supplied with ammonium have lower concentrations of inorganic cations, such as calcium, magnesium and potassium.

\section{Evaluation of SPAD units}

The SPAD units (Fig. 6) increased from 23.3 to 47.7, which agreed with the findings of Asencio (2019), who reported a range of 20.3 to 51 . This species has a range of SPAD units, with varying results for the agroecological environment in which it develops, the state of growth and the availability of water and mineral (Melo et al., 2016). In addition, SPAD units increase in the growth of aerial graft parts through growth processes of the leaf blade and transformation of plastids to chloroplasts, a process called photomorphogenesis, especially with light stimuli, because the

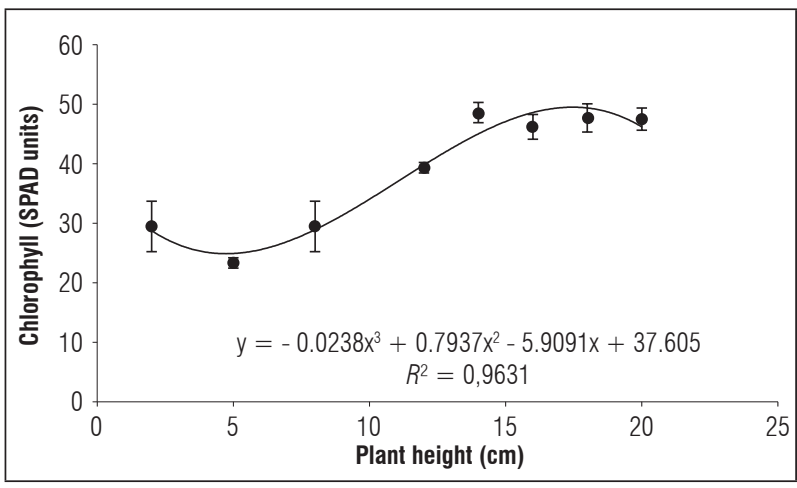

Figure 6. Behavior of SPAD units during the growth stage after grafting plum plants. Error bars indicate standard error. chlorophyll maturation process facilitates the correct identification of the photosynthetic behavior of plants when leaves are true and photosynthetically active (León and Guevara-García, 2008).

The chlorophyll content, leaf area and absorption of incident radiation increase with leaf age (Callejas et al., 2013). The behavior of the chlorophyll content was similar to that found by Asencio (2019).

\section{CONCLUSIONS}

The highest macroelement concentrations with the highest accumulation by the plum plants in nursery stages were found for nitrogen, potassium, magnesium and phosphorus.

Calcium and magnesium concentrations are not an indicator of SPAD units during the early growth stages of plum grafts.

More research on early production stages in individual deciduous fruit trees is recommended for a better conceptualization of nutritional dynamics and to determine nutritional dynamics focused on productive management.

Conflict of interests: The manuscript was prepared and reviewed with the participation of the authors, who declare that there exists no conflict of interest that puts at risk the validity of the presented results.

\section{BIBLIOGRAPHIC REFERENCES}

Aburto-González, C.A., G. Alejo-Santiago, L.G. Ramírez-Guerrero, and R. Sánchez-Hernández. 2017. Concentración foliar de macronutrientes en diferentes etapas fenológicas del litchi cv. Brewster. Interciencia $42(7), 441-445$.

Agronegocios. 2018. Crece la producción de ciruelas en el país, gracias a las tendencias saludables. In: Casa Editorial La República, https://www.agronegocios.co/ agricultura/crece-la-produccion-de-ciruelas-en-el-paisgracias-a-las-tendencias-saludables-2779949; consulted: november, 2020.

Asencio, E.J. 2019. Gestión eficiente de la fertilización nitrogenada en plantaciones frutales de regadío. MSc thesis. Universidad de Extemadura, Badajoz, Spain.

Balta-Crisólogo, R.A., Á.M. Rodríguez-Del castillo, R. Guerrero-Abad, D. Cachique, A.-P. Edín, L. Arévalo-López, and L. Oscar. 2015. Absorción y concentración de 
nitrógeno, fósforo y potasio en sacha inchi (Plukenetia volubilis L.) en suelos ácidos, San Martín, Perú. Folia Amazónica 24(2), 23-30. Doi: 10.24841/fa.v24i2.68

Barragan, E. 2010. Determinación de zonas óptimas para la producción del algodón (Gossypium hirsutum L.) en el valle cálido del alto magdalena por ambiente, rendimiento y calidad de fibra con énfasis en potasio. $\mathrm{PhD}$ thesis. Facultad de Agronomia, Universidad Nacional de Colombia. Bogota.

Bueno, L. and J.C. Camargo. 2012. Cambios del nitrógeno durante etapas de desarrollo temprano de la leucaena (Leucaena leucocephala (Lam.) de Wit). Liv. Res. Rural Dev. 24, http://www.lrrd.org/lrrd24/2/buen24033. htm; consulted: November, 2020.

Bugarín-Montoya, R., M. Virgen-Ponce, A. Galvis-Spinola, D. García-Paredes, T. Hernández-Mendoza, I. Bojorquez-Serrano, and A. Madueño-Molina. 2011. Extracción de nitrógeno en seis especies olerícolas durante su ciclo de crecimiento. Bioagro 23(2), 93-98.

Callejas, R., E. Kania, A. Contreras, C. Peppi, and L. Morales. 2013. Evaluación de un método no destructivo para estimar las concentraciones de clorofila en hojas de variedades de uva de mesa. Idesia 31(4), 19-26. Doi: 10.4067/S0718-34292013000400003

Campos, T.J. 2013. Especies y variedades de hoja caduca en Colombia. pp. 47-65. In: Miranda, D., G. Fischer, and C. Carranza (eds.). Los frutales caducifolios en Colombia - Situación actual, sistemas de cultivo y plan de desarrollo. Sociedad Colombiana de Ciencias Hortícolas, Bogota.

Cárdenas, J. and G. Fischer. 2013. Clasificación botánica y morfología de manzano, peral, duraznero y ciruelo. pp. 21-30. In: Miranda, D., G. Fischer, and C. Carranza (eds.). Los frutales caducifolios en Colombia - Situación actual, sistemas de cultivo y plan de desarrollo. Sociedad Colombiana de Ciencias Hortícolas, Bogota.

Cardona, W.A. 2017. Requerimientos nutricionales (nitrógeno, fósforo, potasio y calcio) en etapa vegetativa y reproductiva de un cultivo de mora (Rubus glaucus Benth.), ubicado en el municipio de Silvania (Cundinamarca). MSc thesis. Facultad de Ciencias Agrarias, Universidad Nacional de Colombia, Bogota.

Castro, A. and G.A. Puentes. 2012. Ciruelo y duraznero (Prunus salicina Lindl.) - (Prunus persica [L.] Batsch.). pp. 370-392. In: Fischer, G. (ed.). Manual para el cultivo de frutales en el trópico. Produmedios, Bogota.

Ciampitti, I.A. and F.O. García. 2008. Requerimientos nutricionales. Absorción y extracción de macronutrientes y nutrientes secundarios. Boletín Técnico, International Plant Nutrition Institute (IPNI), Buenos Aires.

Fernández, J.C., W. Bohórquez, and A. Rodríguez. 2016. Dinámica nutricional del cacao bajo diferentes tratamientos de fertilización con N, P y K en vivero. Rev. Colomb. Cienc. Hortic. 10(2), 367-380. Doi: 10.17584/ rcch.2016v10i2.4702
Fernández, P., F. García, and J. Fernández. 2014. Estimación de las extracciones de nutrientes en el cultivo de ciruelo en la Región de Murcia. Implicaciones del nitrógeno. Actas de Horticultura 66, 167-175.

Fischer, G. and L.M. Melgarejo. 2020. The ecophysiology of cape gooseberry (Physalis peruviana L.) - an Andean fruit crop. A review. Rev. Colomb. Cienc. Hortic. 14(1), 76-89. Doi: 10.17584/rcch.2020v14i1.10893

García, K.I. 2011. Estimulación de la acumulación de biomasa y extracción estacional de nitrógeno, fósforo, potasio, calcio y magnesio en plantas de granado ( $P u-$ nica granatum L.). Undergraduate thesis. Universidad de Chile, Santiago.

García-Ávila, C.J., A.M. Castillo-González, E. Avitia-García, M.T.B. Colinas-León, L.I. Trejo-Téllez, and H. Vargas-Madriz. 2015. Magnesio y su relación con la calidad de Lilium cv. Casablanca. Rev. Mex. Cienc. Agríc. 6(2), 265-276. Doi: Doi: 10.29312/remexca.v6i2.687

González, J. and C.K. del Pardo. 2011. Fertilización en duraznero cv. Flavorcrest. In: IV Jornadas Fertilización SECH. Actas de Horticultura 61, 112-115.

González, M., D. Ríos, K. Peña-Rojas, E. García, M. Acevedo, E. Cartes, and M. Sánchez-Olate. 2020. Efecto de la concentración de fósforo y calcio sobre atributos morfo-fisiológicos y potencial de crecimiento radical en plantas de Aextoxicon punctatum producidas a raíz cubierta en la etapa de endurecimiento. Bosque 41(2), 137-146. Doi: 10.4067/S0717-92002020000200137

González-Pérez, J., A. Becerril-Román, A. Quevedo-Nolasco, C. Velasco-Cruz, and D. Jaén-Contreras. 2018. Peso específico de hoja y concentración de nitrógeno durante la fenología del ciruelo japonés cv. Methley specific leaf weight and leaf nitrogen concentration during the phenolgy of japanese plum cv. Methley. Agroproductividad 11(110), 43-50. Doi: 10.32854/ agrop.v11i10.1243

Jiménez, F. 2017. La importancia de la nutrición con magnesio y azufre en el cultivo de la papa. Infomaciones Agronomicas de Hispanoamerica 26, 30-34.

Latsague, M., P. Sáez, and M. Mora. 2014. Efecto de la fertilización con nitrógeno, fósforo y potasio, sobre el contenido foliar de carbohidratos, proteínas y pigmentos fotosintéticos en plantas de Berberidopsis corallina Hook. f. Gayana. Botánica 71(1), 37-42. Doi: 10.4067/ S0717-66432014000100007

Lema, M., P. Rodríguez, C. Salinero, and F. Veloso. 2010. Seasonal pattern of accumulation of nutrients by kiwifruit 'Hayward' in acid soils of northern Portugal. Acta Hortic. 868, 231-236. Doi: 10.17660/ ActaHortic.2010.868.29

León, P. and A. Guevara-García. 2008. El cloroplasto: un organelo clave en la vida y en el aprovechamiento de las plantas. pp. 223-238. In: López, A. and F. Rebolledo (eds.). Una ventana al quehacer científico. Instituto de Biotecnología, UNAM, Cuernavaca, Mexico. 
Lizarazo, J.C.F., W.B. Santana, and A.R. Villate. 2016. Dinámica nutricional de cacao bajo diferentes tratamientos de fertilización con N, P y K en vivero. Rev. Colomb. Cienc. Hortic. 10(2), 367-380. Doi: 10.17584/ rcch.2016v10i2.4702

López, L.B. and J.C.C. García. 2015. Nitrógeno edáfico y nodulación de Leucaena leucocephala (Lam.) de Wit en sistemas silvopastoriles. Acta Agron. 64(4), 349-354. Doi: 10.15446/acag.v64n4.45362

Marschner, P. (ed.). 2012. Marschner's mineral nutrition of higher plants. $3^{\text {rd }}$ ed. Academic Press; Elsevier, Amsterdam, Netherlands. Doi: 10.1016/C2009-0-63043-9

Martínez, F.E. and G.A. Garcés. 2010. Crecimiento y producción de lechuga (Lactuca sativa L. var. romana) bajo diferentes niveles de potasio. Rev. Colomb. Cienc. Hortic 4(2), 175-184. Doi: 10.17584/rcch.2010v4i2.1239

Melo, W.F., H.E.S. Herrera, S. Magnitskiy, G. Roveda, C.A. Guerrero, and L.P.M. Fonseca. 2016. Efecto de las fuentes de nitrógeno $\left(\mathrm{NH}_{4}\right.$ y $\left.\mathrm{NO}_{3}^{-}\right)$sobre el crecimiento de plantas de gulupa (Passiflora edulis Sims.) en etapa de vivero. In: XX Congreso Internacional de Ciencias Agrícolas, San José de las Lajas, Cuba.

Meses, R. 2010. Curva de absorción de nutrientes para la etapa de vivero de tres materiales de palma aceitera (Elaeis guineensis Jacq.). pp. 1-12. In: Proc. XII Congreso Ecuatoriano de la Ciencia del Suelo. Santo Domingo, Ecuador.

Mixquititla-Casbis, G. and O. Villegas-Torres. 2016. Importancia de los fosfatos y fosfitos en la nutrición de cultivos. Acta Agricola y Pecuaria 2(3), 55-61.

Monsalve, O.I., J.S. Gutiérrez, and W.A. Cardona. 2017. Factores que intervienen en el proceso de mineralización de nitrógeno cuando son aplicadas enmiendas orgánicas al suelo. Una revisión. Rev. Colomb. Cienc. Hortic. 11(1), 200-209. Doi: 10.17584/rcch.2017v11i1.5663

Novoa, M.A., D. Miranda, and L.M. Melgarejo. 2018. Efecto de las deficiencias y excesos de fósforo, potasio y boro en la fisiología y el crecimiento de plantas de aguacate (Persea americana, cv. Hass). Rev. Colomb. Cienc. Hortic. 12(2), 293-307. Doi: 10.17584/ rcch.2018v12i2.8092
Orjuela, M. 2017. Incidencia de las características edáficas y climáticas en el desarrollo del fruto de ciruela variedad Horvin, en el municipio de Nuevo Colón Boyacá. MSc thesis. Facultad de Ingeniería. Universidad Nacional de Colombia, Bogota.

Parra, S., P. Lara, M. Villarreal, and S. Hernández. 2012. Crecimiento de plantas y rendimiento de tomate en diversas relaciones nitrato/amonio y concentraciones de bicarbonato. Rev. Fitotec. Mex. 35(2), 143-153. Doi: 10.35196/rfm.2012.2.143

Puentes. G.A., D.C. Soto, and D.C. Granados. 2019. La planificación de cultivos permanentes, una estrategia empresarial para el cultivo de ciruela en Boyacá Colombia. In: Mem. XXXII Congreso Internacional and II Congreso Iberoamericano en Administración de Empresas Agropecuarias, Guanajuato, Mexico.

Rincón, A. and E. Martínez. 2015. Funciones del calcio en la calidad poscosecha de frutas y hortalizas: una revisión. Alimentos Hoy 23(34), 13-25.

Saini, A.K., H. Singh, S.K. Jawandha, and K.S. Gill. 2020. Influence of Prunus rootstocks and spacing on performance of Japanese plum grown under sub-tropical conditions. Sci. Hortic. 268, 109380. Doi: 10.1016/j. scienta.2020.109380

Salas, M., O. Pernasetti, P. Watkins, and A. Alurralde. 2014. Dinámica del potasio foliar en un ensayo de fertilización potásica en olivo. Infomaciones Agronomicas de Hispanoamerica 16, 21-23.

Ube, S.E. 2019. Importancia del magnesio como macroelemento para el desarrollo y rendimiento del cultivo de arroz (Oryza sativa L.). Undergraduates thesis. Universidad Técnica de Babahoyo, Babahoyo, Ecuador.

Ulloa, M.C., L. Avellán-Vásquez, and N. Cobeña-Loor. 2015. Extracción de micronutrientes según la fenología del plátano barraganete (Musa paradisiaca L.). In: Proc. VII Congreso Sudamericano de Agronomia. Guayaquil, Ecuador.

Villanueva-Couoh, E., G. Alcántar-González, P. Sánchez-García, M. Soria-Fregoso, and A. Larque-Saavedra. 2010. Nutrición mineral con nitrógeno, fósforo y potasio para la producción de Chrysanthemum morifolium Ramat. con sustratos regionales en Yucatán, México. Terra Latinoam. 28(1), 43-52. 